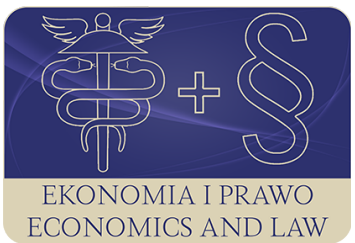

EKONOMIA I PRAWO. ECONOMICS AND LAW

Volume 17, Issue 2, June 2018

p-ISSN 1898-2255, e-ISSN 2392-1625

www.economicsandlaw.pl

EKONOMIA I PRAWO
ECONOMICS AND LAW

ORIGINAL ARTICLE

received 13.06.2017; revised 21.03.2018; accepted 30.06.2018

Citation: Paradowska, (2018). Rivalry and excludability as characteristics of tools aimed at making cycling in cities more attractive. Ekonomia i Prawo. Ecomomics and Law, 17(2): 169-181.

doi:10.12775/EiP.2018.012.

\title{
Rivalry and excludability as characteristics of tools aimed at making cycling in cities more attractive
}

\author{
MONIKA PARADOWSKA \\ University of Wrocław, Faculty of Social Sciences, Institute of International Studies, ul. Koszarowa 3, \\ 51-149 Wrocław, Poland \\ $\square$ monika.paradowska@uwr.edu.pl
}

\begin{abstract}
Motivation: Urban transport systems are complex and sophisticated, while different passenger transport modes are more or less attractive, depending on their characteristics and demands of transport users. According to many municipalities, cycling is considered one of the most required ways of commuting, because it generates multiple benefits and low levels of external costs of transport. Thus, many cities try to increase the share of cycling in the modal split by the way of various interventions. Effects of these efforts are different, depending on levels of rivalry and excludability of goods provided, which influence the attractiveness of cycling.

Aim: The main aim of the paper is (1) to describe key elements of and some solutions for cycling systems in urban areas with focus on two characteristics of goods: rivalry and excludability, and (2) to examine, how different levels of rivalry and excludability influence

the attractiveness of cycling and contribute to required effects of cycling policy.

Results: A change in levels of rivalry and excludability can lead to an increased attractive-ness of cycling. Instruments, that play a crucial role, are e.g. separated cycling infrastructure, leading to a (partially) exclusion of other transport users, as well as solutions for eliminating self-exclusion from cycling or exclusion of people with disabilities. Further research on levels of rivalry and excludability in terms of the complexity of transport systems can contribute to a better understanding of transport behaviour. This, in turn, can result in a creation of adequate solutions and it can be useful while estimating future effects.
\end{abstract}


Keywords: rivalry; excludability; cycling; transport demands; urban transport systems JEL: Q01; R41; R48

\section{Introduction}

The paper focuses on interventions and solutions for improving attractiveness of cycling in cities, as this transport mode combines some benefits of public transport (e.g. relatively high travel speed and short travel time, and thus longer distance available in the same time in comparison to walking) and of walking (e.g. 'active' travelling, 'door-to-door' journeys, independence from timetables in comparison to public transport). There were many studies conducted, which investigated and evaluated cycling policy measures (Pucher et al., 2010). In this paper, a new approach is used, based on levels of rivalry and excludability as characteristics of goods that make up urban cycling systems. The main aim of the paper is (1) to describe key elements and some solutions for cycling systems in urban areas with the focus on levels of rivalry and excludability, and (2) to examine, how different levels of rivalry and excludability influence the attractiveness of cycling and contribute to required effects of cycling policy.

\section{Literature review}

Urban mobility is often given the highest priority among the variety of urban policy goals because efficient urban transport systems enable and stimulate socio-economic development by the way of generating positive external effects (van Audenhove et al., 2014, p. 10; OECD, 2008). On the other hand, negative external effects of transport, especially of individual motorisation, lead to inefficient and unsustainable urban transport systems. This, in turn, often results in a decreased attractiveness and deteriorated functionality of cities (Hall, 1994, pp. 80-81; Clark, 1958; Ricardo-AEA, 2014, UN-Habitat, 2013). One of the most popular solutions is developing and promoting non-motorised transport modes, i.e. walking and cycling, as a real and attractive alternative for cars (see e.g. European Commission (2007a, 2007b)). Nowadays' cities with a high modal share of walking and cycling are praised for their attractiveness, competitiveness, good policy-making and improved wellbeing for inhabitants. The meaning of cycling in urban transport systems cannot be undervalued. There are multiple publications highlighting positive effects resulting from a high share of cycling in the urban modal split, as well as discussing and assessing instruments aimed at enhancing people to choose bikes for their daily trips (see e.g. Pucher \& Buehler (2012); Buehler et al. (2011; 2016)). Moreover, the need for enhancing cycling in cities has been stressed by institutions and organisations at international levels (European Commission, 2011; Lanzendorf \& Busch-Geertsema, 2014). 


\section{Methods}

The paper focuses on analysing levels of rivalry and excludability of goods making up urban cycling systems, and thus it is based on the theory of private and public goods, as well as on some elements of the New Institutional Economics. The theoretical background is used by the Author for her own qualitative analysis of cycling systems in the context of levels of rivalry and excludability. Based on the literature review and the Author's qualitative analysis, the characteristics of selected elements of cycling infrastructure was developed. Then, some elements of transport economics were used for the analysis of the impact of levels of rivalry and excludability on transport behaviour of (potential) cyclists. The results of the literature review and the qualitative analysis are the basis for the formulation of concluding remarks. The author used secondary data and research results presented in scientific papers available in the Web of Science Database and Google Scholar, and other data and information available in online documents.

\section{Motives and triggers for cycling in cities}

The share of cycling in the modal split of urban mobility significantly differs in countries across the world (Pucher \& Buehler, 2008). Many cities in Western Europe are usually highly-ranked not only due to a high share of population using bikes for daily commuting but for developed infrastructure and various interventions enhancing cycling as well (Pucher \& Buehler, 2012; Buehler et al., 2016). There is so-called Copenhagenize Index developed (Zayed, 2016, p. 5 ) to assess, how bike-friendly cities are and to measure the progress that cities do in their efforts to increase the meaning of cycling among all transport modes. The desirable Copenhagen's modal share of cycling, accounting for about 45\%, is still out of reach for the majority of cities in the rest of world. For example, it accounts for $1 \%$ in Australia and for about $2 \%$ in the U.K. and in the U.S. (Buehler et al., 2011; Heesch et al., 2012). Cycling provides multiple benefits in social, economic and environmental spheres (see e.g. Pape (2016)). For this reason, successful cycling policy requires tools and measures that would really change people's views on cycling and their transport behaviour. An important question is, what factors determine 'attractiveness' of cycling for citizens.

It is significant to distinguish different types of city travels because they have a great impact on transport choices. Depending on the destination, travels can be obligatory and regular (e.g. to school or work), incidental and not systematic (e.g. to a doctor) or facultative (e.g. leisure activities) (Rydzkowski \& Wojewódzka-Król, 2007, p. 28). For each travel type, different transport demands and characteristics can be more or less important. For example, when citizens travel to work or school, reliability and punctuality may be of greater importance than e.g. travel time or cost. And similarly, visiting friends or going for small shopping may be an opportunity for physical activity or experiencing 
fresh air and nice environment. Some factors, like accessibility and connectivity of infrastructure, safety, or direct travel between particular points may be equally important, regardless of the travel type or destination. Moreover, different transport demands and characteristics of transport modes can influence transport choices of people in different ways, what is determined by age, gender, social status, mental models and other factors.

Perceptions of 'attractiveness' of urban cycling can vary greatly across individuals. Numerous advantages are underlined while promoting cycling, from keeping fit or saving money to being independent (Dekoster \& Schollaert, 1999; Handy et al., 2014). An important issue is if these benefits are significant for non-cyclists to the same extent as to regular or occasional cyclist. For example, results of some surveys among inhabitants in different cities show, that men usually do nearly three times as many cycling journeys as women (see e.g. Transport for London (2014)). Furthermore, sport and leisure activity, as well as losing weight often prevail in cycling purposes. Even in the most bike-friendly cities in the Netherlands, Denmark and Germany, commuting to work or school accounts for about one-third of all bike trips (Pucher \& Buehler, 2008).

One of the great challenges for cycling strategies is to eliminate constraints for cycling and to provide necessary facilities that would make citizens more likely to choose bikes for their daily trips. Lack of adequate cycling infrastructure has the highest priority among all barriers discouraging people from cycling and, at the same time, expanding such infrastructure is perceived as more than required. This is strictly related to cyclists' concerns about safety, both in objective and subjective sense (Pape, 2016, p. 9). Thus, many cities make huge efforts to provide infrastructure measures leading to an increase in the number of cyclists. However, not so surprisingly, the real effects of developing cycling infrastructure are not always in line with intended ones (Pucher \& Buehler, 2016; Mayes et al., 1996). Thus, improving the attractiveness of cycling needs a special approach. These issues will be elaborated a little bit more deeply in the further parts of this paper in terms of rivalry and excludability.

\section{The meaning of rivalry and excludability in urban cycling systems}

According to Samuelson (1954), two key types of goods can be distinguished: pure private goods that are both excludable and rivalrous in consumption, and pure public goods, non-excludable and non-rivalrous in their character. The third type of good, namely a club good, has been added by Buchanan (1965). Club goods are non-rivalrous for their users, who have the possibilities to exclude others from using by the way of setting a price. Although mainly the problem, who should provide different types of goods, and the possibility for pricing were key factors that time for analysing features of different goods, rivalry and excludability have influenced economic studies in many other ways, including Hardin's tragedy of the commons (1968) and common pool resources stud- 
ied by E. Ostrom (1990). Furthermore, inefficiencies and failures of markets and governments in providing, allocating and governing different types of goods stimulated deeper research and analysis of levels of rivalry and excludability. Key observations and remarks made by E. Ostrom $(1990 ; 2010)$ is that rivalry and excludability are not 'present or absent' but rather vary from low to high. Table 1 presents main types of goods based on levels of rivalry and excludability.

Key elements of cycling systems in cities are different types of cycling roads, available means of transport (bikes), parking places, intersections, different facilities, like signage, traffic lights etc. In transport policies aimed at increased bikes' usage, some other aspects play a significant role as well, for example, facilities integrating cycling with public transport, bike boxes, lack of infrastructure barriers etc. (Mayes et al., 1996). What is necessary to mention is that elements of cycling infrastructure and other elements of urban cycling systems have features of different goods listed in table 1 . These characteristics influence numbers of aspects related to cycling in cities, namely incentives and responsibilities for provision (elimination) of specific goods (e.g. elements of infrastructure, cycling regulations, constraints discouraging from cycling etc.), profile of people that are likely to cycling, levels of satisfying particular transport demands, perceived adequacy of cycling for different travel purposes etc. The character of these impacts is strictly related to rivalry and exclusion. For example, some people can be unlikely to cycle to work, as they need to share the road with other transport users what makes them feel unsafe because a high level of rivalry exists. On the other hand, even separated bike paths (low level of rivalry) can be unattractive for inexperienced cyclists, because regular cyclists go too fast and incalculably. This, in turn, can be considered a reason for 'self-exclusion' of inexperienced cyclists. Self-exclusion in such a case can be understood as resigning from cycling by a person due to factors making riding a bike difficult or even impossible - in the opinion of this person. It can result from many factors, such as lack of information about existing infrastructure, concerns about finding a parking place, fear of getting a cold because of weather conditions etc. Usually, it is unintended and/or unrequired, similar to exclusion of disabled or older people, in contrast to intended and/or required exclusion of e.g. cyclists from footpaths. What is important in cycling policy is that some goods are provided intentionally, in order to eliminate self-exclusion or unintended exclusion of disabled people.

An interesting concept is that some goods are characterised by anti-rivalry and anti-excludability (De Vries, 2005; Levinson, 2014). According to the De Vries (2005), the use of anti-rivalrous goods 'increases the amount available for consumption by others', while anti-excludability means that the use of a good encourages other people to consumption, what can be the case of cyclists attracting others to ride a bike. These concepts, though very appealing in terms of analysing attractiveness of cycling, are used only to a small extent in this paper. 


\section{Impacts of levels of rivalry and excludability on incentives and motives for urban cycling}

In reality, the whole transport system has features of a club good (Platje, 2012), though it consists of many various elements characterised by different levels of rivalry and excludability. The same situation relates to cycling systems. Nearly everyone can use all elements of the system taken together. The level of excludability is not high - there are always some cheap bikes available and minimum levels of physical skills are required. However, cycling can be something impossible for people with disabilities, unless special facilities are provided. Additionally, self-exclusion can lead to a low share of cycling in cities due to perceived, often subjective constraints for riding a bike. Table 2 presents levels of rivalry and excludability of some basic elements of cycling systems.

The first most important conclusion resulting from table 2 is that cycling infrastructure exposing cyclists to a high rivalry, especially with users of motor vehicles, negatively influences the attractiveness of cycling. The main reason is that some significant transport demands of cyclists are or can be satisfied at lower levels (see table 3). Moreover, an efficient cycling system requires high accessibility and connectivity, i.e. a real network of high quality, safe bike roads, and paths. People can resign from cycling, even if almost entire commute distance they use is safe, isolated from cars etc., but one short part induces cycling on a narrow bike lane close to cars or there is a dangerous intersection with the road. Potholes, high curbs on a bike road or cars parked beside or on a bike lane can be deterrents causing unintended and/or unrequired exclusion from cycling, both being a matter of choice or a real barrier e.g. for children, disabled people etc. (see e.g. Winters et al. (2011); Mayes et al. (1996)). Lack of safety due to forcible rivalry with car users on shared elements of infrastructure can be a factor discouraging women who consider cycling, especially with children. Increasing the number or length of cycling routes in cities does not necessarily lead to an expected increase in the share of cyclists in the modal split because shared spaces or bike lanes are considered unattractive. This is the main reason why separated, good quality bike paths generate the best effects. Sometimes cyclist prefer to use footpaths than lanes shared with cars, though it makes them look bad due to breaking road regulations and causing danger to pedestrians (Pucher \& Buehler, 2016). Finally, a large number of stops due to e.g. traffic lights, intersections without priority etc. makes cycling less attractive (Heydon \& Lucas-Smith, 2014).

In order to remove obstacles to cycling, some solutions are implemented that have features of public goods (e.g. maintenance of bike infrastructure, free bike stations with full service, free and secure parking) or of club goods for cyclists, aimed at different kind of exclusion of car users (Pucher et al., 2010). These interventions can have dissimilar impacts on regular or occasional cyclists as well as on non-cyclists. Someone, who has never cycled due to different factors, can be unlikely to commute by bike, even when many improvements and facili- 
ties are provided. Thus, free educational programmes (a 'near-public' or public good) or special tandem programmes for people with disabilities (a club good) are introduced, inter alia to eliminate self-exclusion or unrequired exclusion of disabled people (Pucher et al., 2010).

In table 3 there are some examples presented of impacts of levels of rivalry and exclusion on transport demands related to cycling. Cycling, though it has many advantages, is often not perceived as a close substitute for commuting by car. Moreover, high levels of rivalry with car drivers in access to infrastructure make bikes less attractive. Therefore, developing cycling infrastructure and introducing educational programmes can be not enough for a real shift from cars to bikes. As the example of London City shows, measures aimed at the exclusion of cars, e.g. by additional pricing, caused a large increase in bike travels in the city centre, with a relatively stable modal split in London's downtown and suburbs (Wright, 2016). Moreover, effects of anti-rivalry and anti-excludability shouldn't be undervalued, as they can contribute not only to fashion for cycling but to first steps on the way to changing people's mental models related to preferred transport modes.

\section{Conclusion}

The article focuses on levels of rivalry and excludability of basic elements of cycling infrastructure and their impact on the attractiveness of cycling in cities. A brief analysis presented above points to the following key conclusions:

- High levels of rivalry, especially with car drivers, are likely to negatively influence the attractiveness of cycling in cities. Safety, travel time and speed are one of the most important transport demands affected by high levels of rivalry.

- Intended exclusion of car drivers, pedestrians and other transport users by the way of providing separated, non-shared cycling infrastructure can lead to an improved attractiveness of cycling.

- Separated cycling infrastructure allowing for experiencing fresh air and nature can cause an effect of anti-exclusion, and attract people that usually ride a bike e.g. for leisure and recreation.

- Accessibility and connectivity need to be ensured by the cycling infrastructure as a whole. Higher levels of rivalry and/or some other deterrents can lead to self-exclusion or real exclusion of some potential cyclists.

- Improved cycling infrastructure can have no influence on the elimination of self-exclusion. Some other interventions aimed at provision of public or club goods (e.g. educational programmes) can be necessary to change people's mental models.

- Transport demands vary among different types of cyclists and non-cyclists and can be satisfied at various levels, depending on levels of rivalry and excludability. Thus, rivalry and excludability as characteristics of ele- 
ments of cycling infrastructure need to be considered while creating tools aimed at making cycling more attractive.

- A great focus should be on avoiding exclusion of people with disabilities or special needs. This can be done by providing club goods or public goods within a cycling-inclusive transport policy.

What is important to mention is that rivalry and excludability influence transport choices and behaviour of all transport users. For this reason, cycling policy needs to be integrated with other transport policies in order to make whole transport systems efficient and to generate expected changes and shifts between transport modes. Further research on levels of rivalry and excludability in terms of the complexity of transport systems can contribute to a better understanding of transport behaviour, to the creation of adequate solutions and to a better estimation of future effects.

\section{References}

Buchanan, J. (1965). An economic theory of clubs. Economica, 32(125). doi:10.2307/2552442.

Buehler, R., Götschi, T., \& Winters, M. (2016). Moving toward active transportation: how policies can encourage walking and bicycling. San Diego: Active Living Research.

Buehler, R., Pucher, J., Merom, D., \& Bauman, A. (2011). Active travel in Germany and the US. Contributions of daily walking and cycling to physical activity. American Journal of Preventive Medicine, 41(3). doi:10.1016/j. amepre.2011.04.012.

Clark, C. (1958). Transport: maker and breaker of cities. Town Planning Review, 28(4). doi:10.3828/tpr.28.4.kun370rn6pg882g3.

De Vries, P. (2005). Anti-rival and anti-excludable. Retrieved 20.11.2016 from http://deepfreeze9.blogspot.com.

Dekoster, J., \& Schollaert, U. (1999). Cycling: the way ahead for towns and cities. Retrieved 20.11.2016 from http://ec.europa.eu.

European Commission. (2007a). Sustainable Urban Transport Plans. Preparatory Document in relation to the follow-up of the Thematic Strategy on the Urban Environment. Main document. Retrieved 20.11.2016 from http://ec.europa.eu.

European Commission. (2007b). Sustainable Urban Transport Plans. Preparatory Document in relation to the follow-up of the Thematic Strategy on the Urban Environment. Annex. Retrieved 20.11.2016 from http://ec.europa.eu.

European Commission. (2011). Roadmap to a Single European Transport Area: towards a competitive and resource efficient transport system. Retrieved 20.11.2016 from http://ec.europa.eu.

Hall, P. (1994). Squaring the circle: can we resolve the Clarkian paradox? Environment and Planning B: Planning and Design, 21(7). doi:10.1068/b21s079. 
Handy, S., van Wee, B., \& Kroesen, M. (2014). Promoting cycling for transport: research needs and challenges. Transport Reviews, 34(1). doi:10.1080/0 1441647.2013.860204.

Hardin, G. (1968). The tragedy of the commons. Science, 162(3859). doi:10.1126/ science.162.3859.1243.

Heesch, K.C., Sahlqvist, S., \& Garrard, J. (2012). Gender differences in recreational and transport cycling: a cross-sectional mixed-methods comparison of cycling patterns, motivators, and constraints. International Journal of Behavioral Nutrition and Physical Activity, 9(1). doi:10.1186/1479-5868-9-106.

Heydon, R., \& Lucas-Smith, M. (2014). Making space for cycling. A guide for new developments and street renewals. London: Cyclenation.

Lanzendorf, M., \& Busch-Geertsema, A. (2014). The cycling boom in large German cities - empirical evidence for successful cycling campaigns. Transport Policy, 36. doi:10.1016/j.tranpol.2014.07.003.

Levinson, D., (2014). Rivalry and anti-rivalry, excludability and anti-excludability. Retrieved 20.11.2016 from https://transportist.org.

Mayes, M., Halliday, M., \& Hatch, I. (1996). A qualitative assessment of attitudes to cycling. Transport policy and its implementation. London: Planning and Transport Res and Computation.

OECD. (2008). Thewidereconomic benefits of transport: macro-, meso- andmicro-economic transport planning and investment tools. doi:10.1787/9789282101834-en.

Ostrom, E. (1990). Governing the commons. The evolution of institutions for collective action. Cambridge: Cambridge University Press. doi:10.1017/ CBO9780511807763.

Ostrom, E. (2010). Beyond markets and states: polycentric governance of complex economic systems. American Economic Review, 100(3). doi:10.1257/ aer.100.3.641.

Pape, M. (2016). Moving cycling forward: coordinated approach to cycling for local and regional authorities in the EU. Retrieved 20.11.2016 from http:/ / www.europarl.europa.eu.

Platje, J. (2012). Current challenges in the economics of transport systems: a stakeholder and club good approach. Logistics and Transport, 2(15).

Pucher, J., \& Buehler, R. (2008). Making cycling irresistible: lessons from the Netherlands, Denmark and Germany. Transport Reviews, 28(4). doi:10.1080/01441640701806612.

Pucher, J., \& Buehler, R. (2012). Walking and cycling in Western Europe and the United States: trends, policies, and lessons. TR News, 280.

Pucher, J., \& Buehler, R. (2016). Safer cycling through improved infrastructure. American Journal of Public Health, 106(12). doi:10.2105/AJPH.2016.303507.

Pucher, J., Dill, J., \& Handy, S. (2010). Infrastructure, programs and policies to increase cycling: an international review. Preventive Medicine, 50(S1). doi:10.1016/j.ypmed.2009.07.028.

Ricardo-AEA. (2014). Update of the handbook on external costs of transport. Retrieved 20.11.2016 from https://ec.europa.eu. 
Rydzkowski, W., \& Wojewódzka-Król, K. (Eds.). (2007). Transport. Warszawa: PWN.

Samuelson, P. (1954). The pure theory of public expenditure. Review of Economics and Statistics, 36(4). doi:10.2307/1925895.

Transport for London. (2014). Attitudes towards cycling. Annual report 2014. Retrieved 22.03.2017 from http://content.tfl.gov.uk.

UN-Habitat. (2013). Planning and design for sustainable urban mobility. Global report on human settlements 2013. Retrieved 20.11.2016 from https://unhabitat.org.

van Audenhove, F.J., Korniichuk, O., Dauby, L., \& Pourbaix, J. (2014). Future of urban mobility 2.0. Imperatives to shape extended mobility ecosystems of tomorrow. Retrieved 16.03.2017 from http://www.uitp.org.

Winters, M., Davidson, G., Kao, D., \& Teschke, K. (2011). Motivators and deterrents of bicycling: comparing influences on decisions to ride. Transportation, 38(1). doi:10.1007/s11116-010-9284-y.

Wright, P. (2016). Congestion charging: lessons from London. London: Transport for London.

Zayed, M. A. (2016). Towards an index of city readiness for cycling. International Journal of Transportation Science and Technology, 5(3). doi:10.1016/j. ijtst.2017.01.002.

\section{Acknowledgements}

Author contributions: author has given an approval to the final version of the article.

Funding: this research was fully funded by the University of Opole.

Note: the results of this study were presented at 9th International Conference on Applied Economics Contemporary Issues in Economy (June 22-23, Torun, Poland). 


\section{Appendix}

Table 1.

\section{Different types of goods}

\begin{tabular}{|c|c|c|c|}
\hline Specification & Non-excludability & Partial excludability & Excludability \\
\hline perfect rivalry & $\begin{array}{c}\text { open access (tragedy of the com- } \\
\text { mons) }\end{array}$ & $\begin{array}{l}\text { private good featuring high control } \\
\text { costs }\end{array}$ & private good \\
\hline partial rivalry & $\begin{array}{l}\text { impure public good with some } \\
\text { rivalry, but no exclusion }\end{array}$ & congestion good & club good \\
\hline no rivalry & pure public good & $\begin{array}{l}\text { impure public good with some } \\
\text { exclusion }\end{array}$ & excludable public good \\
\hline
\end{tabular}

Source: Platje (2012, p. 46).

\section{Table 2.}

\section{Characteristics of selected elements of cycling infrastructure}

\begin{tabular}{ll}
\hline Elements of infrastructure & \multicolumn{1}{c}{ Rivalry/excludability } \\
\hline $\begin{array}{l}\text { one road for all transport } \\
\text { users }\end{array}$ & $\begin{array}{r}\text { very high (perfect) rivalry among all } \\
\text { types of transport users/no one is } \\
\text { excluded from use, but self-exclusion } \\
\text { can exist }\end{array}$ \\
\hline $\begin{array}{l}\text { on-road bicycle lanes, } \\
\text { markings from lanes for } \\
\text { motor vehicles }\end{array}$ & $\begin{array}{c}\text { Low or high levels of rivalry among } \\
\text { the width of the lane, one-way or two- } \\
\text { way bike traffic etc.; levels of rivalry } \\
\text { with car drivers depend on the be- } \\
\text { haviour of drivers/non-cyclists are } \\
\text { excluded from using bike lanes }\end{array}$
\end{tabular}

bike lanes shared with buses/taxi drivers and bike paths shared with pedestrians levels of rivalry with other users can be different, but it is generally lower than on roads shared with cars/different types of transport users can be excluded, depending on the specific solution
An open access regime can lead to a 'tragedy of commons' in this sense, that using the road is inconvenient for many or for all users, not only because of congestion. Cyclists can resign due to lack of safety, air pollution, behaviours of drivers etc.

A club good for cyclists, prone to congestion. Demarcating bike lanes by painted markings do not create physical barriers for motor vehicles. There is still a high probability of an accident and exposure to air pollution. 'Dishonest' car drivers can use the bike road (a free-rider problem). Too narrow bike lanes can lead to higher levels of rivalry among all users

Congestion good/a club good for cyclists, bus and (or) taxi drivers/pedestrians.

Depending on the type of separation, car drivers can cause a free-rider problem.

Self-exclusion can exist when some transport demands of cyclists are not met (e.g. speed, conditions for cycling). In peak hours rivalry can be very high, what can negatively influence the attractiveness of using shared space. off-road bike paths, physically separated from car infrastructure

rivalry only with other cyclists, low or high, depending on their number and the character of a path/exclusion of other transport users
A club good for cyclists with a low or very low probability of a free-rider problem caused by car drivers (this problem can result from the behaviour of some other transport users - pedestrians, skaters etc.). for cyclists, low level of rivalry with

bike boxes (advanced stop lines) 


\begin{tabular}{|c|c|c|}
\hline Elements of infrastructure & Rivalry/excludability & Comments \\
\hline traffic lights and signage & $\begin{array}{l}\text { there is nearly no rivalry and exclusion } \\
\text { in use (except specific situations) }\end{array}$ & $\begin{array}{l}\text { Both separate (only for cyclists), as well as } \\
\text { shared traffic lights and signage have fea- } \\
\text { tures of a public good. Facilities designed } \\
\text { for cyclists make the access and utility } \\
\text { strictly adjusted to cyclists' needs. }\end{array}$ \\
\hline $\begin{array}{l}\text { bike-sharing (bike-rental) } \\
\text { systems }\end{array}$ & $\begin{array}{l}\text { the level of rivalry increases together } \\
\text { with an increase in the number } \\
\text { of users/exclusion of people who don't } \\
\text { pay the fee (or do not meet other } \\
\text { requirements, like registration, having } \\
\text { a special card etc.) }\end{array}$ & $\begin{array}{c}\text { Depending on the number of users } \\
\text { and the ease of access, bike-sharing } \\
\text { systems can be considered different types } \\
\text { of goods, e.g. club goods (there are bikes } \\
\text { and bike stations available for all registered } \\
\text { users) or congestion goods (no bikes and/ } \\
\text { or free places at bike stations in peak } \\
\text { hours). }\end{array}$ \\
\hline intersections & $\begin{array}{c}\text { depending on the character of infra- } \\
\text { structure and types of users, levels } \\
\text { of rivalry and exclusion vary from low } \\
\text { to high }\end{array}$ & $\begin{array}{l}\text { Different facilities (e.g. road traffic } \\
\text { regulations, traffic lights) can prevent in- } \\
\text { tersections from becoming an open access } \\
\text { regime and from the tragedy of commons. }\end{array}$ \\
\hline
\end{tabular}

Source: Own preparation.

Table 3.

\section{Examples of impacts of levels of rivalry and excludability on selected transport demands related to cycling}

\begin{tabular}{|c|c|c|}
\hline Transport demands & Levels of rivalry & Levels of exclusion \\
\hline $\begin{array}{l}\text { accessibility and con- } \\
\text { nectivity }\end{array}$ & $\begin{array}{l}\text { High levels of rivalry, especially with car } \\
\text { drivers, can be perceived as a factor nega- } \\
\text { tively affecting connectivity (intersections) } \\
\text { or accessibility of some cycling infrastruc- } \\
\text { ture. }\end{array}$ & $\begin{array}{c}\text { Self- or real exclusion due to infrastructure } \\
\text { deterrents (potholes, too narrow bike lanes) } \\
\text { leading to poor connectivity can discourage } \\
\text { from cycling. }\end{array}$ \\
\hline \multirow[t]{2}{*}{ price/travel costs } & \multirow{2}{*}{$\begin{array}{c}\text { Increase in demand for cycling can lead } \\
\text { to higher prices of private goods provided } \\
\text { via markets, higher costs of bike services } \\
\text { etc. }\end{array}$} & $\begin{array}{l}\text { Exclusion of other transport users (e.g. } \\
\text { charging system in London City) can lead } \\
\text { to an increase in prices due to greater } \\
\text { demand for cycling. }\end{array}$ \\
\hline & & $\begin{array}{l}\text { Bike-sharing systems allow for cycling at } \\
\text { low costs and eliminate some types of exclu- } \\
\text { sion. }\end{array}$ \\
\hline \multirow{3}{*}{$\begin{array}{l}\text { travel time and travel } \\
\text { speed }\end{array}$} & \multirow{3}{*}{$\begin{array}{l}\text { The majority of bike lanes/paths are } \\
\text { congestion-prone goods, thus an increased } \\
\text { number of users and shared lanes, } \\
\text { intersections etc. can lead to longer travel } \\
\text { time. Separated bike paths can make levels } \\
\text { of rivalry lower. } \\
\text { Looking for a free parking place or bike } \\
\text { station can make the travel time longer. }\end{array}$} & $\begin{array}{c}\text { Purposefully exclusion of other transport } \\
\text { users usually leads to lower levels of rivalry } \\
\text { and congestion, positively influencing travel } \\
\text { time. }\end{array}$ \\
\hline & & Shared spaces with pedestrians usually \\
\hline & & $\begin{array}{l}\text { make people cycle more carefully, what } \\
\text { makes them cycling slower. }\end{array}$ \\
\hline \multirow[t]{2}{*}{ ‘door-to-door’ travel } & \multirow{2}{*}{$\begin{array}{l}\text { A bike, similar to a car or walking, offers } \\
\text { the possibility of a direct travel, but high } \\
\text { levels of rivalry in terms of parking space } \\
\text { available can weaken this effect. }\end{array}$} & $\begin{array}{c}\text { Exclusion of cars from using some roads or } \\
\text { parking space can cause that only walking } \\
\text { and cycling would allow for 'door-to-door' } \\
\text { travels in cities. }\end{array}$ \\
\hline & & $\begin{array}{l}\text { Lack of bicycle parking or unsecure parking } \\
\text { can cause self-exclusion (cyclists are afraid } \\
\text { of thefts) or real exclusion (stolen bike). }\end{array}$ \\
\hline
\end{tabular}




\begin{tabular}{|c|c|c|}
\hline Transport demands & Levels of rivalry & Levels of exclusion \\
\hline safety & $\begin{array}{l}\text { Due to its features, cycling is considered less } \\
\text { safe than driving a car. High levels of rival- } \\
\text { ry, especially with car users, usually make } \\
\text { cycling less safe (Pucher \& Buehler, 2016). } \\
\text { Traffic lights and other 'near-public' goods } \\
\text { dedicated for cyclists can make cycling } \\
\text { safer. } \\
\text { Anti-rivalry can exist, e.g. when the pres- } \\
\text { ence of other cyclists make someone feel } \\
\text { safer. }\end{array}$ & $\begin{array}{l}\text { Bicycle infrastructure that excludes other } \\
\text { transport users can make cycling safer } \\
\text { (objectively) and make people feel safer } \\
\text { (subjectively), positively influencing the at- } \\
\text { tractiveness of cycling. } \\
\text { Lack of exclusion in case of street lights, } \\
\text { traffic lights etc. makes the overall level } \\
\text { of safety higher. }\end{array}$ \\
\hline $\begin{array}{l}\text { reliability } \\
\text { and punctuality }\end{array}$ & $\begin{array}{l}\text { The higher the level of rivalry, the higher } \\
\text { the risk of an accident and the higher } \\
\text { the probability of congestion. }\end{array}$ & $\begin{array}{l}\text { As in examples presented above - exclusion } \\
\text { of car users etc. can lead to an improved } \\
\text { reliability and punctuality of a journey. }\end{array}$ \\
\hline information & $\begin{array}{l}\text { 'Near-public' goods or club goods, such as } \\
\text { online cycling maps, mobile apps for cyclists } \\
\text { etc. usually are non-rivalrous and provide } \\
\text { the required information. }\end{array}$ & $\begin{array}{c}\text { Some people without a computer, a smart- } \\
\text { phone or skills and knowledge how to use it } \\
\text { can be excluded. Partially exclusion doesn't } \\
\text { have a positive impact on cycling among } \\
\text { affected groups. }\end{array}$ \\
\hline comfort & $\begin{array}{l}\text { Though bikes can hardly meet some trans- } \\
\text { port demands that are easily met by private } \\
\text { cars, some infrastructure elements can be } \\
\text { designed strictly for cycling (no rivalry with } \\
\text { other transport users) and make it more } \\
\text { comfortable. } \\
\text { The fewer rivals in the cycle route, the bet- } \\
\text { ter comfort. However, anti-rivalry can take } \\
\text { place, e.g. when people cycle with friends } \\
\text { or family members. }\end{array}$ & $\begin{array}{l}\text { Exclusion of other transport users (sepa- } \\
\text { rated infrastructure) can lead to a better } \\
\text { comfort of cycling. }\end{array}$ \\
\hline $\begin{array}{l}\text { health } \\
\text { and environmental } \\
\text { aspects }\end{array}$ & $\begin{array}{l}\text { No rivalry with cars usually positively } \\
\text { influences health aspects of cycling. } \\
\text { Anti-rivalry can occur, when cycling by } \\
\text { some citizens allows other cyclists to breath } \\
\text { fresh, not polluted air. }\end{array}$ & $\begin{array}{l}\text { If there is an effect of anti-exclusion, people } \\
\text { cycling to work, shops or for leisure can } \\
\text { attract other people due to health and envi- } \\
\text { ronmental reasons. }\end{array}$ \\
\hline
\end{tabular}

\section{Source: Own preparation.}


